\title{
Musculoskeletal and cognitive effects of stochastic resonance whole body vibration: A Randomized Controlled Trial
}

\author{
Yannik Faes, ${ }^{1}$ Cornelia Rolli Salathé, ${ }_{1}^{1}$ Céline Cébe, ${ }^{1}$ Andreas Szukics, ${ }^{1}$ Achim Elfering ${ }^{1 \star}$
}

\begin{abstract}
Introduction: We investigated the acute musculoskeletal and cognitive effects of stochastic resonance whole-body vibration (SR-WBV). To our knowledge, no study looked at the effects of SR-WBV on inhibitory control so far. Materials and Methods: In this randomized controlled trial, participants were randomly allocated into a verum $(6 \mathrm{~Hz}, \mathrm{SR}-\mathrm{WBV})$ or sham ( $2 \mathrm{~Hz}, \mathrm{SR}-\mathrm{WBV}$ ) condition. Inhibitory control was measured with the Stroop Test before and after the exercise. Also, muscle stiffness, muscle relaxation, sense of balance and surefootedness were assessed in a questionnaire before and after the exercise. Results: Inhibitory control increased significantly after verum SR-WBV $(\mathrm{t}=2.949, \mathrm{P}=0.018)$, but not after sham SR-WBV $(t=1.165, P=0.252)$. Muscle stiffness decreased significantly after verum $(t=5.273, P<0.000)$, but not after sham SR-WBV $(\mathrm{t}=1.533, \mathrm{P}=0.135)$. Also, muscle relaxation increased significantly after verum $(\mathrm{t}=-2.879, \mathrm{P}=$ $0.007)$, but not after sham SR-WBV $(t=-1.650, P=0.108)$. Sense of balance increased significantly after verum $(\mathrm{t}=-2.061, \mathrm{P}=$ 0.047), but not after sham SR-WBV ( $\mathrm{t}=0.347, \mathrm{P}=0.730$ ). No significant effect was found in surefootedness, whether after verum $(t=-0.966, P=0.341)$ nor after sham SR-WBV $(t=0.849$, $\mathrm{P}=0.402)$. Conclusions: SR-WBV seems to be an appropriate method to improve not only physiological measurements but newly also cognition, i.e. inhibitory control. In this study we could show that SR-WBV exercise reduces interference and increases inhibitory control in a young and healthy sample.
\end{abstract}

Keywords: Stochastic resonance whole body vibration (SRWBV); Musculoskeletal effects; Cognitive effects; Inhibitory control; Randomized controlled trial.

\section{Resumo}

Efeitos musculoesqueléticos e cognitivos da vibração de corpo inteiro por ressonância estocástica (SR-WBV)

Introdução: Investigamos os efeitos musculoesqueléticos e cognitivos da vibração de corpo inteiro por ressonância estocástica (stochastic resonance whole-body vibration, SR-WBV). Até o momento, não temos conhecimento de outro estudo analisando os efeitos doSR-WBV no controle inibitório. Materiais e Métodos: Neste estudo controlado randomizado, os participantes foram alocados em uma condição verum (6 $\mathrm{Hz}, \mathrm{SR}-\mathrm{WBV}$ ) ou falsa (2 Hz, SR-WBV). O controle inibitório foi medido com o Stroop Test antes e após o treino. Além disso, a rigidez muscular, o relaxamento muscular, o senso de equilíbrio e a firmeza foram avaliados em um questionário
1. Department of Work and Organizational Psychology, University of Bern, Bern 3012, Switzerland.

*Correspondence address:

Department of Work and Organizational Psychology

University of Bern Fabrikstrasse 8

Bern 3012, Switzerland

E-mail: achim.elfering@psy.unibe.ch

BJHBS, Rio de Janeiro, 2020;19(1):20-30

Received on 01/07/2020. Approved on 04/24/2020.

antes e após o treino. Resultados: O controle inibitório aumentou significativamente após o SR-WBV verum $(t=2,949$, $P=0,018)$, mas não após SR-WBV falso $(t=1,165, P=0,252$. $A$ rigidez muscular diminuiu significativamente após o verum $(\mathrm{t}=5,273 \mathrm{P}<0,000)$, mas não após a simulação do SR-WBV $(\mathrm{t}=$ $1,533 \mathrm{P}=0,135$ ). Além disso, o relaxamento muscular aumentou significativamente após o verum ( $\mathrm{t}=-2,879, \mathrm{P}=0,007)$, mas não após o falso SR-WBV ( $\mathrm{t}=-1.650, \mathrm{P}=0,108)$. O senso de equilíbrio aumentou significativamente após o verum $(\mathrm{t}=-2,061$, $P=0,047)$, mas não após o falso SR-WBV $(t=0,347, P=0,730)$. Nenhum efeito significativo foi encontrado na firmeza, seja após verum $(\mathrm{t}=-0,966, \mathrm{P}=0,341)$ nem após SR-WBV falso $(\mathrm{t}=$ 0,849, P = 0,402). Conclusões: OSR-WBV parece um método de treino apropriado para melhorar não apenas as medidas fisiológicas, mas também a cognição, isto é, o controle inibitório. Neste estudo, pudemos mostrar que o treino com SR-WBV reduz a interferência e aumenta o controle inibitório em uma amostra jovem e saudável.

Descritores: Vibração de corpo inteiro por ressonância estocástica (SR-WBV); Efeitos musculoesqueléticos; Efeitos cognitivos; Controle inibitório; Estudo controlado randomizado.

\section{Resumen}

Efectos musculoesqueléticos y cognitivos agudos de la Vibración Corporal de Resonancia Estocástica (SR-WBV)

Introducción: En este estudio, investigamos los efectos musculoesqueléticos y cognitivos agudos de la Vibración Corporal de Resonancia Estocástica (SR-WBV por sus siglas en inglés). Hasta el momento, no tenemos conocimiento de ningún estudio analizando los efectos de la SR-WBV en el control de la inhibición. Materiales y Métodos: En esta prueba controlada aleatoria, 
los participantes fueron asignados al azar a una condición de tratamiento $(6 \mathrm{~Hz}$, SR-WBV) o simulada (2 Hz, SR-WBV). Hemos medido la capacidad de control de inhibición con la prueba de Stroop antes y después del entrenamiento. Además, la rigidez muscular, la relajación muscular, el sentido del equilibrio y la estabilidad fueron evaluados mediante un cuestionario antes y después del entrenamiento. Resultados: El control de la inhibición aumentó significativamente después del tratamiento SR-WBV $(t=2,949, P=0,018)$, pero no después de la simulación deSR-WBV ( $\mathrm{t}=1,165, \mathrm{P}=0$,252). La rigidez muscular disminuyó significativamente después del tratamiento $(t=5,273 \mathrm{P}<0,000)$, pero no después de la simulación SR-WBV $(\mathrm{t}=1,533 \mathrm{P}=0,135)$. Además, la relajación muscular aumentó significativamente después del tratamiento $(t=-2,879, P=0,007)$, pero no después de la simulación de SR-WBV $(t=-1,650, P=0,108)$. El sentido

\section{Introduction}

Stochastic resonance whole-body vibration (SRWBV) is an effective exercise, which is also very easy to carry out. A number of studies have shown that SR-WBV improves musculoskeletal well-being and reduces musculoskeletal pain for example in metal manufacturing workers, ${ }^{1}$ in office workers ${ }^{2}$ and in adults with chronic disease. ${ }^{3}$ Elfering et al. ${ }^{4}$ reported an improvement of musculoskeletal relaxation immediately after SR-WBV exercise. Also, SR-WBV increases surefootedness, balance and postural control for example in nurses or office workers. ${ }^{5-7}$

The positive effects described above are supported by particularly good compliance rates on the part of study participants. In a hospital based trial there was a $100 \%$ participation rate. ${ }^{8}$ Even better than this, office workers had a training attendance of $129 \%$, hence more than instructed. ${ }^{5}$ Elfering et al. ${ }^{2}$ explain that $\mathrm{SR}-\mathrm{WBV}$ is low in nonmonetary effort compared to conventional exercises. The exercising duration is about 10 minutes short and is not exhausting, so users do not sweat and therefore do not have to change clothes or take a shower. This is important especially in occupational settings or in healthy young adults, where participants do not want to waste time.

SR-WBV differs notably from sinusoidal sidealternating WBV (SS-WBV) and sinusoidal vertical WBV (SV-WBV), ${ }^{9,10}$ two established training types. Compared to these variations of sinusoidal WBV, force impacts in SR-WBV are not predictable (i.e. stochastic), and therefore the human body is constantly challenged to adapt its neural and muscular reactions. ${ }^{11}$ Due to this, the nerve-muscle system learns to respond adequately in a short amount of time and thus enhances its reactivity. ${ }^{12}$ del equilibrio aumentó significativamente después del tratamiento $(t=-2,061, P=0,047$ ), pero no después de la simulación de SR-WBV ( $t=0,347, \mathrm{P}=0,730)$. No se encontró ningún efecto significativo en la estabilidad, ni después del tratamiento $(\mathrm{t}=$ $-0,966, P=0,341)$ ni después de la simulación de SR-WBV ( $t=$ $0,849, \mathrm{P}=0,402)$. Conclusiones: Encontramos indicios de que la SR-WBV podría ser un método de entrenamiento apropiado para mejorar no sólo las mediciones fisiológicas sino también la cognición, más precisamente, el control inhibitorio. En este estudio pudimos demostrar que el entrenamiento con SR-WBV reduce las interferencias y aumenta el control inhibitorio en un grupoe de participantes jovenes y sanos.

Palabras clave: Vibración Corporal de Resonancia Estocástica (SR-WBV); Efectos musculoesqueléticos; Efectos cognitivos; Control de inhibición; Prueba controlada aleatoria.

However, WBV does not only seem to have effects on a physical level. Recent studies described promising effects of sinusoidal WBV in sitting position on cognition of healthy individuals as well as on cognition in individuals with ADHD, ${ }^{13}$ in healthy young adults, ${ }^{14}$ and in healthy children ${ }^{15}$ indicating improvement of inhibitory control. The study of cognitive effects of vibration exercises is quite new and the underlying process is not fully understood yet. It is documented, that the improvement of inhibitory control through vibration training can be explained by the connection between sensory brain regions and the prefrontal cortex. Due to this connection, there is an increased neurotransmission in the prefrontal cortex because of sensory stimulation, such as vibration training. ${ }^{16,17}$ Also, first experiments with mice could show that there are positive effects of WBV on neurotransmitter systems and cognition. . $^{1819}$ To our knowledge, no studies investigated the effects of SR-WBV on cognitive performances so far.

\section{What is inhibitory control?}

Executive functions, such as inhibitory control, attention, cognitive flexibility and decision making, are higher order cognitive abilities that help us provide goal-directed behavior by demonstrating self-control. ${ }^{20,21}$

Inhibitory control thereby describes the ability to deliberately suppress dominant, automatic responses or impulsive reactions if necessary, in order to favor the alternative, planned behavior. ${ }^{22,23}$

For example, when a pack of toothpicks falls from the kitchen cupboard on to the hot stove, the reflexive reaction would be to pick them up. Inhibitory control 
helps us to stop or to regulate our automatic reaction so we do not try to pick them up and burn our hand. Instead, we might reach for a cooking spoon in order to push them aside.

A validated task to measure inhibitory control is the Stroop Test. ${ }^{24}$ In this task the participant needs to overcome, or to inhibit the automatic tendency to react with a dominant response. Therefore, participants need to ignore the written name of the color in order to name the ink color of the word, which represents a goal-directed behavior.

A recent meta-analysis describes various effects of WBV on elderly and physically stricken persons. ${ }^{25}$ Sparse literature exists regarding the physical effects of WBV in younger people. Morel and colleagues, ${ }^{26}$ however, described improved physical conditions in younger people in sports. We want to contribute to that and expect in this experimental study an increase of inhibitory control immediately after one session of SR-WBV (H1), based on previous studies with sinusoidal vibration. ${ }^{13-15}$ In line with studies that reported musculoskeletal effects, 4,9,11,27 we expect a decrease of muscle stiffness and an increase of muscle relaxation (H2), as well as an increase in sense of balance and surefootedness (H3). Acute effects are expected in the verum-condition (vibration frequency: $6 \mathrm{HzSR}-\mathrm{WBV}$ ), but not in the sham-condition (2 Hz SR-WBV).

\section{Materials and methods}

\section{Ethics}

The study was performed in consensus with all requirements defined by the Swiss Society of Psychology and was conducted with the understanding and the consent of the human subject. The Ethical Committee of the responsible University faculty (University of Bern) has approved the study (Nr. 201807-00002).

\section{Participants}

Expecting a moderate effect size $(d=0.5)$ for the t-test analysis between two dependent means and a requirement of $90 \%$ power to detect an existing difference, the required sample size was 28 participants for each exercising condition, verum and sham. Only participants with good health were allowed to attend the study.

Exclusion criteria for this study were being pregnant, having osteosynthesis material (such as implants, screws, etc.) in the body, musculoskeletal disorders, joint problems (especially regarding the knee, hip and back), herniated discs, rheumatism (such as spondylitis, gout, osteoporosis, osteoarthritis), cardiovascular complaints, disorders related to the sense of balance (such as hearing loss). Also, participants should take part when in a rested condition and must not have had any intensive workout within the last 24 hours, as it might influences musculoskeletal and cognitive effects. They must also not suffer from redgreen color blindness or take medication known to affect the central nervous system, in order to be able to attend the Stroop Test. ${ }^{24}$

Seventy-three students and acquaintances signed up for the study, with 2 participants not showing up and one participant not being able to take part due to screws in his knee. Seventy participants took part in the study, each group was comprised of 35 participants. Students of the associated university who participated in the study were rewarded with one of 15 mandatory participant-hours. Acquaintances were thanked with sweets after the experiment.

\section{Vibration platform}

Two SRT-Zeptor Medical plus noise (FreiSwiss AG, Zurich, Switzerland) were used in this study. This vibration platform consists of two independent, one-dimensional (up/down) stochastically oscillating footboards with $3 \mathrm{~mm}$ amplitude and two passive degrees of freedom (forward/backward, left/right). The footboards also allow medial and lateral tilting, which leads to pluridimensional movement.

Participants were instructed to stand on the footboards in an upright position with slightly bent knees (i.e., a skiing posture) and with their arms hanging loosely at their sides. The verum SR-WBV condition was set at a frequency of $6 \mathrm{~Hz}$. This frequency is slightly higher than the minimal effective stimulation parameter of $5 \mathrm{~Hz}$ and is most applied when participants have free choice. The sham SR-WBV condition was set at a frequency of $2 \mathrm{~Hz}$ which we expect to have no effect. ${ }^{4}$ In order to prevent participants from seeing the vibration frequency, the setting-screen was covered with a piece of paper.

\section{Measurement of inhibitory control}

The Stroop Color Word Test ${ }^{24}$ is a well-established paradigm to measure cognitive interference and inhibitory control. ${ }^{28}$ It was assessed on a computer 
with the program Inquisit $5 \mathrm{Lab}$ (Millisecond Software LLC, Seattle, USA). Participants were given color words written in color and were asked to indicate the ink color of the word and ignoring the dominant tendency of reading the word by pressing a key as fast and correct as they could. The test consisted of congruent (color word, e.g. "yellow" and the color it is presented in is the same, hence yellow), incongruent (color word, e.g. "blue" and the color it is presented in is not the same, e.g. red) and neutral items (colored rectangles in red, green, blue or black. After a test trial, the experimental trial with 84 randomly sampled items started. It lasted approximately 3 minutes.

As mentioned in the meta-analysis of Laird et al. ${ }^{29}$ to measure inhibitory control, the incongruent items are compared to a control condition which consists of congruent, neutral or non-lexical items. The difference in performance between the control condition and incongruent condition is called the interference effect with a larger difference indicating a higher interference and a lower inhibitory control. ${ }^{30}$

To reduce problems concerning latency-time in keyboards ${ }^{31}$ we used reaction response boxes V1.0 (c) immo electronics) with 4 buttons to react to the 4 presented colors. These buttons were placed in front of the participants who held their fingers (index- and middle finger of each hand) ready on the buttons during the test. Figure 1 shows the Stroop Test on a computer set-up.

\section{Questionnaire assessment}

Muscle stiffness and muscle relaxation were assessed using a short version of the self-administered questionnaire of Burger et al. ${ }^{1}$ before and after the exercise. The questions were answered on a 100-pointrating-scale from zero ("not stiff"; "not relaxed") to 100 ("as stiff as possible"; "as relaxed as possible").

Sense of balance and surefootedness were assessed with validated questions "How do you rate your personal feelings about your balance?" and "How surefooted do you feel?" before and after the exercise.,5 Participants answered on a rating-scale from 0 being "a lot worse than usual" to 100 being "much better than usual", and with 50 being "same as always". No practical tests to determine the balance were carried out.

In addition to these outcomes, demographics were assessed in the questionnaire after the exercise. The questionnaire assessment was run by Qualtrics@ (2016 Qualtrics LLC).

\section{Procedure}

The experiment took place at a laboratory at the University of Bern and was carried out by 2 examiners (CC, AS). The first examiner gave the instructions to the participants, while the second acted as his assistant. The roles of first and second examiner were changed regularly in order to prevent monotony. Up to 4 participants could attend the tests at the same time. When there were less than 3 participants, all tests were carried out by one examiner. To make sure the procedure was standardized, a case report form (CRF) was used to conduct the approximately 45-minute experiment, which is described below.

Participants read the study-information and signed

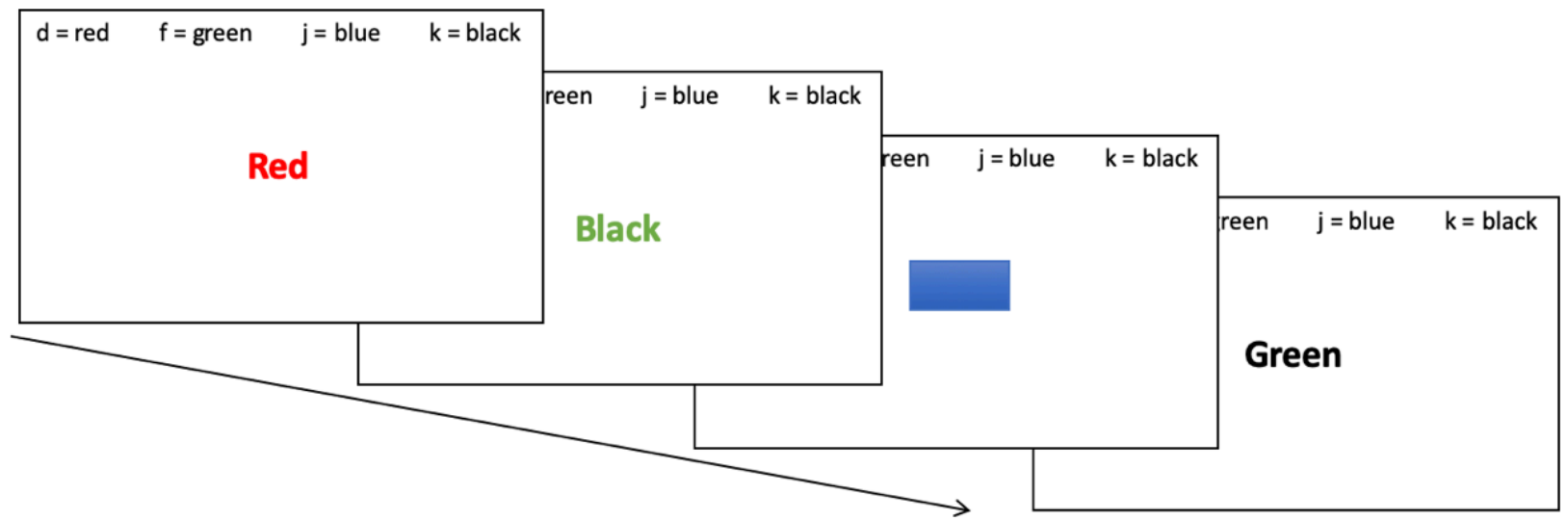

Figure 1. Stroop Test on a computer set-up

The Stroop Color Word Test consisted of congruent (color word and the color it is presented in are the same), incongruent (color word and the color it is presented in are not the same) and neutral items (colored rectangles in red, green, blue or black. After a test trial, the experimental trial with $\mathbf{8 4}$ randomly sampled items started. It lasted approximately 3 minutes 


\section{Original article}

a consent form. The examiner explained the overall procedure without revealing the group allocation. After answering the first questionnaire participants attended the Stroop Color Word Test on the computer. Prior to testing, a coin was flipped and participants were randomly assigned to a verum $(6 \mathrm{~Hz})$ or sham $(2$ $\mathrm{Hz}$ ) SR-WBV condition. When arriving, participants were blinded with respect to their exercising condition. However, a blinding of the examiners was not feasible.

During the SR-WBV exercise, participants stood in an upright position as described above. As in previous studies, ${ }^{1,2,27}$ one session consisted of five series, that lasted one minute each with a one-minute break in between. In this short break participants could loosen up and prepare for the following series. In the post-measurements, participants completed the Stroop Color Word Test before they answered the questionnaire as it was especially important to assess the immediate effects of the SR-WBV exercise on inhibitory control. The whole procedure is shown in Figure 2.

\section{Statistical analysis}

Cognitive interference, muscle stiffness and muscle relaxation, as well as balance and surefootedness were analyzed in a dependent sample t-test to examine differences between baseline and exercising conditions. P-values were two-tailed with $\alpha$-level set at 5\%. Collected variables were not approximately normally distributed $(\mathrm{p}<.05)$ as assessed by Shapiro-Wilk Test. By including graphical approaches as well as skewness and kurtosis into the decision, it showed that all variables were close to normal. Also, because of the same group size, analyses of the hypotheses can be considered robust against violations of the normal distribution.32

Descriptive statistics for the sample are shown in Table 1.

\section{Results}

\section{Participant characteristics}

Seventy healthy students and acquaintances (94\% students; $80 \%$ female; mean age $=23.11$ years, $\mathrm{SD}=3.65$ years; $\mathrm{BMI}=21.83 \pm 3.03$ ) took part in this study. They were randomly assigned to verum or sham condition $(\mathrm{n}=35)$. Although, the two groups did not differ significantly in any other demographic characteristics or in baseline inhibitory control, muscle stiffness,

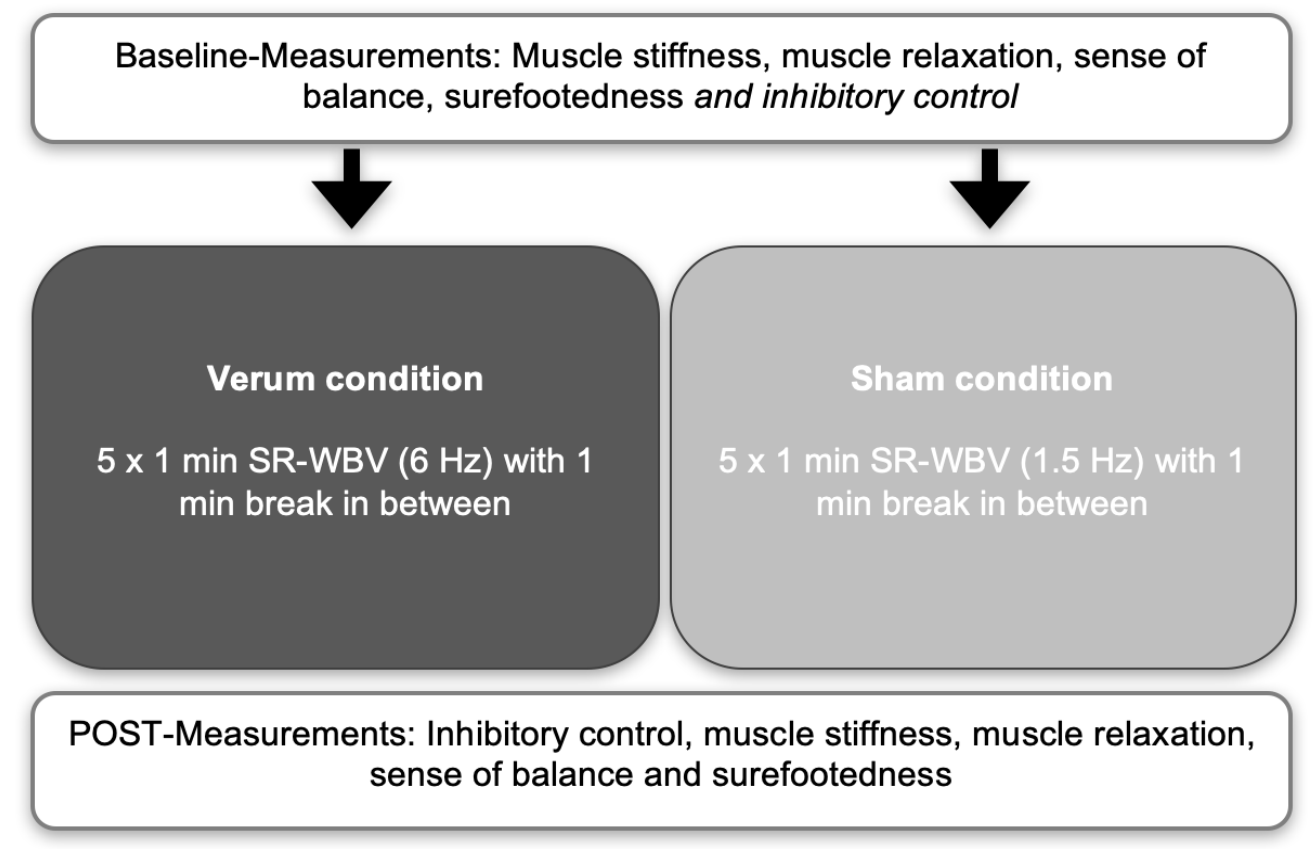

Figure 2. Flowchart of the procedure

Muscle stiffness, muscle relaxation, sense of balance and surefootedness were assessed in a questionnaire before and after SR-WBV exercise. Performance in a Stroop Test before and after SR-WBV exercise showed the amount of cognitive interference, i.e. inhibitory control 
muscle relaxation, as well as self-reported balance or surefootedness, the verum condition included more males than the sham condition. Also, participants in the verum condition were slightly older (23.97 \pm 4.21) than participants in the sham condition (22.26 $\pm 2.80)$, although not significant $(t=2.00, \mathrm{P}=0.050)$. Table 2 depicts correlations between study variables for verum and sham condition separately. Male participants have lower BMI than female participants $\left(-.374^{*}\right)$, but only in the verum condition. In the sham condition only, younger participants were more often female than male $\left(-.557^{* *}\right)$ and surprisingly, sporty participants showed higher cognitive interference at baseline $\left(.356^{\star}\right)$ and better sense of balance after the SR-WBV exercise (.455**). Unsurprisingly, sense of balance and surefootedness were highly correlated at baseline (verum: $.874^{* *}$; sham: $.499^{* *}$ ) and after the exercise (verum: .712**; sham: $.550^{* *}$ ). Interestingly, surefootedness and muscle stiffness were negatively correlated at baseline (verum: -.418*; sham: $-.526^{* *}$ ) and after the exercise (verum: -0.205 (n.s.); sham: -.405*), whereas surefootedness was positively correlated with muscle relaxation at baseline (verum: 0.257 (n.s.); sham: $.479^{* *}$ ) and after the exercise (verum: $.420^{*}$; sham: 0.144 (n.s.). T-test results and descriptive statistics for both exercising conditions are shown in Table 3.

Overall, we found promising effects for the verum SR-WBV condition, but not for the sham condition, indicating acute musculoskeletal and cognitive effects of SR-WBV.
Better inhibitory control after verum SR-WBV (H1)

A significant smaller interference effect was found after verum SR-WBV $(t=2.949, \mathrm{P}=0.018, \mathrm{n}=35)$, but not after sham SR-WBV $(\mathrm{t}=1.165, \mathrm{P}=0.252, \mathrm{n}=35)$. Compared to baseline measurement (verum: $4.90 \pm 6.19$; sham: $4.39 \pm 9.84$ ) the difference in answer correctness between congruent and incongruent items decreased significantly in verum $(1.12 \pm 5.32)$, but not in sham condition ( $2.65 \pm 5.22)$. Effect sizes are, according to Cohen, ${ }^{33}$ described as small $(d=0.2)$, medium $(d=0.5)$, and large $(d \geq 0.8)$. Effect sizes using Cohen's $d^{33}$ on interference in the verum condition was $d=0.655$, and in the sham condition $\mathrm{d}=0.206$.

Lower muscle stiffness and higher muscle relaxation after verum SR-WBV (H2)

A significant effect on muscle stiffness was found after verum SR-WBV $(t=5.273 \mathrm{P}<0.000, \mathrm{n}=30)$, but not after sham SR-WBV $(\mathrm{t}=1.533 \mathrm{P}=0.135, \mathrm{n}=30)$. Compared to baseline measurement (verum: $10.54 \pm 8.00$; sham: $13.37 \pm 10.58$ ) muscle stiffness significantly decreased after verum ( $3.83 \pm 5.39$ ), but not after sham SR-WBV (10.11 \pm 10.55 ). Effect sizes using Cohen's $d^{33}$ on muscle stiffness in the verum condition was $d=-0.959$, and in the sham condition $\mathrm{d}=-0.308$.

A significant effect on muscle relaxation was found after verum SR-WBV $(\mathrm{t}=-2.879, \mathrm{P}=0.007, \mathrm{n}=$ $30)$, but not after sham SR-WBV ( $\mathrm{t}=-1.650, \mathrm{P}=0.108$, $\mathrm{n}=30$ ). Compared to baseline measurement (verum: $75.86 \pm 25.10$; sham: $77.14 \pm 17.51)$ muscle relaxation

Tabela 1. Descriptive and inferential statistics

\begin{tabular}{|c|c|c|c|c|c|c|}
\hline \multirow[b]{2}{*}{ Variable } & \multicolumn{2}{|c|}{ Verum $(n=35)$} & \multicolumn{2}{|c|}{ Sham $(n=35)$} & \multirow[b]{2}{*}{$t$} & \multirow[b]{2}{*}{$P$} \\
\hline & $\mathbf{M}$ & SD & $\mathbf{M}$ & SD & & \\
\hline $\operatorname{Sex}(m, f)$ & $12 m, 23 f$ & & $2 m, 33 f$ & & & \\
\hline Age (yr.) & 23.97 & 4.21 & 22.26 & 2.80 & 2.00 & .050 \\
\hline $\mathrm{BMI}\left(\mathrm{kg} / \mathrm{m}^{2}\right)$ & 22.27 & 2.75 & 21.39 & 3.27 & 1.22 & .226 \\
\hline Sport (1 "never" - 7 "daily+") & 4.97 & 1.40 & 5.23 & 1.11 & -.85 & .399 \\
\hline Smoking (yes, no) & $4 y, 31 n$ & & $4 y, 31 n$ & & & \\
\hline BL Cognitive Interference & 4.90 & 6.19 & 4.39 & 9.84 & .26 & .796 \\
\hline BL Muscle Stiffness & 10.54 & 8.00 & 13.37 & 10.58 & -1.26 & .211 \\
\hline BL Muscle Relaxation & 75.86 & 25.10 & 77.14 & 17.51 & -.25 & .804 \\
\hline BL Sense of Balance & 47.91 & 7.18 & 47.83 & 4.42 & .06 & .952 \\
\hline BL Surefootedness & 48.03 & 6.24 & 48.20 & 5.62 & -.12 & .904 \\
\hline
\end{tabular}

Sport: Amount of Sport was measured using a 7-point likert-scale from 1 "never" to 7 "several times a day"; being a smoker and having children were answered with yes (y) or no (n); Baseline (BL) Variables: Cognitive Interference was calculated as the difference between correctness $(100 \%=$ all correct) in congruent trials minus the correctness in incongruent trials. Higher interference stands for lower inhibitory control; Muscle stiffness muscle relaxation was assessed on a 100-point-rating-scale from 0 "not at all comfortable" to 100 "as comfortable as you can imagine"; Sense of Balance and Surefootedness were answered from 0 "a lot worse than usual" to 100 "much better than usual" and with 50 being "same as always"; p-values are two-tailed with an a-level set at 5\% 


\section{Original article}

\begin{tabular}{|c|c|c|c|c|c|c|c|c|c|c|c|c|c|c|c|c|}
\hline س & $\stackrel{\stackrel{\leftrightarrow}{N}}{\stackrel{0}{0}}$ & $\begin{array}{l}\stackrel{\Xi}{0} \\
0 \\
0\end{array}$ & 孚 & 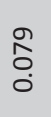 & 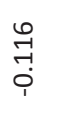 & $\begin{array}{l}\infty \\
\stackrel{0}{0} \\
0\end{array}$ & $\begin{array}{l}\infty \\
0 \\
0 \\
i\end{array}$ & 惫 & 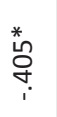 & $\begin{array}{l}0 \\
0 \\
0 \\
i\end{array}$ & $\begin{array}{l}\underset{J}{J} \\
\stackrel{-}{0}\end{array}$ & $\begin{array}{l}\text { ָ̊ } \\
\stackrel{i}{1}\end{array}$ & $\begin{array}{l}\text { 营 } \\
\text { 员 }\end{array}$ & & $r$ & 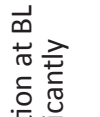 \\
\hline 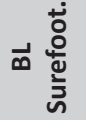 & $\begin{array}{l}\infty \\
0 \\
0 \\
0\end{array}$ & $\begin{array}{c}\vec{N} \\
\text { i } \\
1\end{array}$ & ֻั & $\begin{array}{l}\stackrel{\infty}{0} \\
0 \\
0 \\
1\end{array}$ & $\begin{array}{l}\text { ஜे } \\
0 \\
0\end{array}$ & 号 & 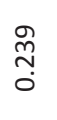 & 晜 & 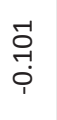 & 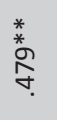 & $\begin{array}{l}\text { Ĩ } \\
0 \\
0\end{array}$ & 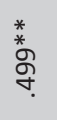 & $\begin{array}{c}\stackrel{n}{1} \\
\stackrel{-}{0} \\
1\end{array}$ & $r$ & 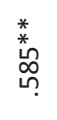 & 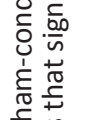 \\
\hline 山 $\frac{\stackrel{\Xi}{\frac{\pi}{\pi}}}{\frac{\pi}{\pi}}$ & 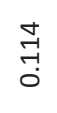 & $\begin{array}{l}\hat{-} \\
\text { - } \\
0\end{array}$ & $\begin{array}{l}\text { ¿̊ } \\
0\end{array}$ & 㪗 & $\begin{array}{l}\text { ôे } \\
\text { i. }\end{array}$ & $\begin{array}{l}\text { \& } \\
\stackrel{\circ}{न 1} \\
0\end{array}$ & $\begin{array}{l}\text { 峝 } \\
\text { O. }\end{array}$ & $\begin{array}{l}\stackrel{\infty}{0} \\
\stackrel{0}{0}\end{array}$ & $\begin{array}{l}\infty \\
\infty \\
0 \\
0\end{array}$ & $\begin{array}{l}\stackrel{N}{N} \\
\stackrel{1}{1}\end{array}$ & $\begin{array}{l}\text { ô } \\
\text { م} \\
\text { ị }\end{array}$ & $\begin{array}{l}\text { N} \\
\stackrel{1}{1} \\
\stackrel{0}{1}\end{array}$ & $r$ & 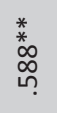 & $\stackrel{*}{\stackrel{*}{*}} \underset{ }{ }$ & 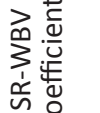 \\
\hline 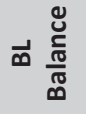 & Oे. & $\begin{array}{l}0 \\
\stackrel{0}{0} \\
\stackrel{1}{1}\end{array}$ & $\begin{array}{l}\tilde{O} \\
\stackrel{0}{0}\end{array}$ & $\begin{array}{c}\text { Oे } \\
\stackrel{0}{0}\end{array}$ & $\begin{array}{l}0 \\
0 \\
0 \\
1\end{array}$ & $\begin{array}{l}\text { J } \\
\text { Oे } \\
0\end{array}$ & 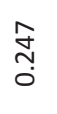 & 苂 & $\begin{array}{l}\infty \\
\infty \\
\stackrel{1}{1} \\
1\end{array}$ & $\underset{\substack{\stackrel{2}{n} \\
0}}{ }$ & 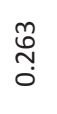 & $r$ & $\begin{array}{l}\stackrel{*}{*} \\
\stackrel{*}{n}\end{array}$ & 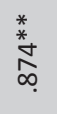 & 莘 & \\
\hline$\sum_{w}^{\dot{\Sigma}} \frac{\dot{x}}{\underline{\omega}}$ & 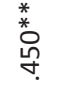 & : & $\begin{array}{l}\text { mo } \\
0\end{array}$ & $\begin{array}{l}\tilde{0} \\
0 \\
0\end{array}$ & $\stackrel{*}{\stackrel{*}{\Delta}}$ & 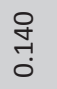 & 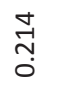 & $\begin{array}{l}\text { m } \\
0 \\
0 \\
1\end{array}$ & 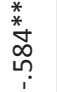 & $\begin{array}{l}\stackrel{*}{*} \\
\stackrel{\infty}{+} \\
\stackrel{f}{*}\end{array}$ & $r$ & 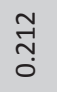 & $\stackrel{\stackrel{*}{*}}{\stackrel{m}{n}}$ & 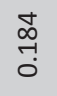 & $\stackrel{*}{*}$ & \\
\hline$\sum_{\bar{\omega}}^{\dot{\Sigma}} \frac{\dot{x}}{\frac{\pi}{\varrho}}$ & 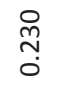 & 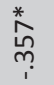 & $\begin{array}{l}\hat{m} \\
\stackrel{m}{0} \\
i\end{array}$ & $\begin{array}{l}\stackrel{0}{m} \\
\stackrel{0}{0} \\
1\end{array}$ & $\begin{array}{l}\mathscr{O} \\
\stackrel{\tilde{O}}{0} \\
0\end{array}$ & $\begin{array}{l}\stackrel{t}{0} \\
\stackrel{1}{0}\end{array}$ & 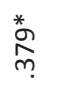 & $\stackrel{*}{*} \stackrel{*}{\stackrel{*}{q}}$ & 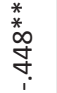 & $r$ & 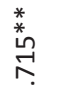 & 竎 & 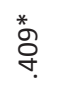 & 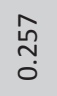 & 菊 & \\
\hline$\sum_{w}$ & 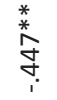 & 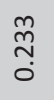 & $\begin{array}{l}\hat{0} \\
\text { ồ }\end{array}$ & そ̊ & $\begin{array}{l}0 \\
\stackrel{\leftrightarrow}{\circ} \\
0\end{array}$ & $\begin{array}{l}\overrightarrow{0} \\
0 \\
0 \\
i\end{array}$ & 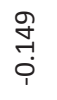 & ָิ & -1 & $\begin{array}{l}\stackrel{-1}{7} \\
\stackrel{1}{1}\end{array}$ & $\underset{\stackrel{N}{N}}{\stackrel{n}{i}}$ & $\begin{array}{l}\stackrel{-}{7} \\
\stackrel{1}{1}\end{array}$ & $\begin{array}{l}\stackrel{2}{\rightarrow} \\
\stackrel{9}{1}\end{array}$ & $\begin{array}{l}0 \\
\text { On } \\
\text { î }\end{array}$ & 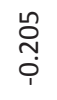 & \\
\hline$\sum_{\dot{\infty}}^{\dot{E}}$ & $\stackrel{\text { n }}{\stackrel{7}{7}}$ & 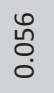 & $\begin{array}{l}\stackrel{T}{\sim} \\
\stackrel{1}{1}\end{array}$ & $\begin{array}{l}n \\
\stackrel{n}{0} \\
0\end{array}$ & \begin{tabular}{l}
$\infty$ \\
$\stackrel{\infty}{\circ}$ \\
\hdashline \\
0
\end{tabular} & $\begin{array}{l}\overrightarrow{\tilde{N}} \\
\stackrel{0}{1}\end{array}$ & $\begin{array}{l}\stackrel{N}{N} \\
\stackrel{i}{1}\end{array}$ & $r$ & $\stackrel{*}{\vec{I}}$ & $\begin{array}{l}\stackrel{0}{7} \\
\stackrel{0}{1}\end{array}$ & $\begin{array}{l}0 \\
0 \\
0 \\
1\end{array}$ & $\stackrel{\substack{* \\
\infty}}{\infty_{i}^{\infty}}$ & $\stackrel{*}{\stackrel{*}{m}}$ & 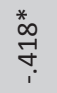 & $\stackrel{*}{\underset{7}{7}}$ & \\
\hline ن & $\underset{\text { Iี }}{0}$ & $\begin{array}{l}\hat{o} \\
\text { ô } \\
\text { in }\end{array}$ & \begin{tabular}{l}
\multirow{2}{*}{} \\
$\stackrel{0}{0}$ \\
0
\end{tabular} & $\begin{array}{l}\stackrel{\infty}{\pi} \\
0\end{array}$ & $\begin{array}{l}\tilde{o} \\
\text { ò }\end{array}$ & 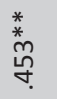 & $\rightarrow$ & 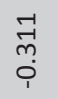 & 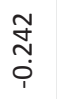 & $\begin{array}{l}\text { 尺े } \\
\text { రิ }\end{array}$ & 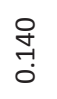 & 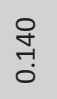 & $\stackrel{*}{\stackrel{*}{\mathrm{~m}}}$ & $\stackrel{\infty}{\stackrel{\infty}{N}}$ & $\stackrel{*}{\underset{7}{7}}$ & \\
\hline 芯芯 & $\begin{array}{l}\stackrel{0}{0} \\
0 \\
0 \\
i\end{array}$ & :̊ & \begin{tabular}{l}
0 \\
\multirow{1}{1}{} \\
$\vdots$ \\
1
\end{tabular} & $\begin{array}{l}\stackrel{*}{0} \\
\stackrel{\leftrightarrow}{\stackrel{n}{n}}\end{array}$ & 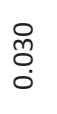 & $\rightarrow$ & $\begin{array}{l}\stackrel{0}{0} \\
\stackrel{1}{1}\end{array}$ & 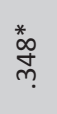 & 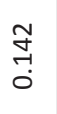 & $\begin{array}{l}0 \\
\stackrel{0}{1} \\
\stackrel{1}{1}\end{array}$ & $\begin{array}{l}\stackrel{n}{n} \\
\stackrel{\leftrightarrow}{1} \\
\stackrel{1}{1}\end{array}$ & 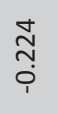 & $\stackrel{\substack{n \\
0}}{0}$ & $\begin{array}{l}\text { fo } \\
\text { i }\end{array}$ & 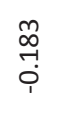 & \\
\hline 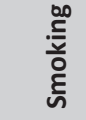 & 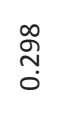 & 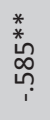 & ্ָণ & $\begin{array}{l}\hat{o} \\
0 \\
\end{array}$ & -1 & $\begin{array}{l}\stackrel{\hat{N}}{\sim} \\
\stackrel{i}{i}\end{array}$ & 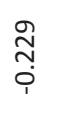 & $\begin{array}{l}\stackrel{J}{\sim} \\
\stackrel{i}{i}\end{array}$ & 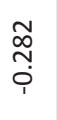 & 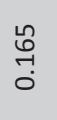 & $\begin{array}{l}\text { 号 } \\
\stackrel{\leftrightarrow}{0}\end{array}$ & $\begin{array}{l}\dot{\tilde{O}} \\
0 \\
0\end{array}$ & 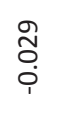 & $\begin{array}{l}\hat{n} \\
0 \\
0 \\
i\end{array}$ & $\begin{array}{l}\vec{I} \\
\stackrel{0}{0}\end{array}$ & $\sum_{\substack{\alpha \\
\alpha}}^{\infty}$ \\
\hline $\begin{array}{l}\text { to } \\
\text { के }\end{array}$ & $\begin{array}{l}n \\
\stackrel{1}{7} \\
i \\
1\end{array}$ & $\begin{array}{l}\text { ¿ } \\
\text { ने } \\
\text { ị }\end{array}$ & $\begin{array}{l}\tilde{N}_{0} \\
\text { Oे. }\end{array}$ & $\rightarrow$ & $\begin{array}{l}\hat{\stackrel{D}{2}} \\
\stackrel{i}{i}\end{array}$ & $\begin{array}{l}\stackrel{n}{0} \\
\stackrel{0}{0}\end{array}$ & $\begin{array}{l}0 \\
0 \\
0 \\
i \\
1\end{array}$ & $\begin{array}{l}\text { ñ } \\
\text { ôे }\end{array}$ & 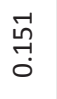 & $\begin{array}{l}\text { ¿े } \\
0 \\
0\end{array}$ & $\begin{array}{l}0 \\
\stackrel{1}{0} \\
0\end{array}$ & $\begin{array}{l}\text { ơ } \\
\text { i. }\end{array}$ & $\begin{array}{l}\text { ¿̀ } \\
\text { o. } \\
\text { i. }\end{array}$ & $\begin{array}{l}0 \\
\text {-1 } \\
\text { i. }\end{array}$ & 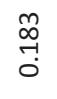 & 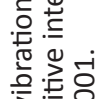 \\
\hline $\bar{\Sigma}$ & 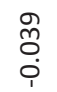 & $\begin{array}{l}0 \\
\text { ŏ } \\
\text { i. }\end{array}$ & $r$ & 우 & 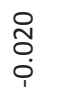 & $\stackrel{*}{\stackrel{*}{*}}$ & $\begin{array}{l}m \\
\stackrel{n}{0} \\
0\end{array}$ & $\begin{array}{l}\hat{o} \\
0 \\
i\end{array}$ & $\begin{array}{l}\stackrel{7}{m} \\
\stackrel{m}{0} \\
i\end{array}$ & $\begin{array}{l}\hat{n} \\
\text { On } \\
0\end{array}$ & 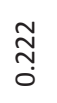 & $\begin{array}{l}\stackrel{0}{7} \\
\stackrel{\leftrightarrow}{0} \\
i\end{array}$ & 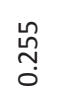 & $\begin{array}{l}\widetilde{N} \\
\tilde{0} \\
0\end{array}$ & $\begin{array}{l}0 \\
0 \\
0 \\
0 \\
i\end{array}$ & \\
\hline 品 & $\begin{array}{l}\stackrel{*}{*} \\
\stackrel{*}{n} \\
\end{array}$ & 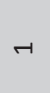 & $\stackrel{n}{\stackrel{n}{0}}$ & 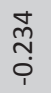 & $\begin{array}{l}\stackrel{0}{0} \\
0 \\
0 \\
0\end{array}$ & $\begin{array}{l}\text { o } \\
\text { t. } \\
\text { i }\end{array}$ & $\begin{array}{l}m \\
\stackrel{m}{0} \\
\dot{0}\end{array}$ & 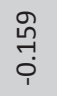 & 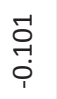 & $\begin{array}{l}\infty \\
\stackrel{0}{0} \\
0 \\
1\end{array}$ & $\begin{array}{l}\text { 员 } \\
\text { ○े }\end{array}$ & $\underset{\stackrel{J}{7}}{\stackrel{\sim}{0}}$ & $\begin{array}{l}\stackrel{0}{\leftrightarrow} \\
\text { ب̣ }\end{array}$ & $\begin{array}{l}0 \\
\stackrel{7}{7} \\
0 \\
0\end{array}$ & స్ํํ & \\
\hline હ & $r$ & $\begin{array}{l}\mathscr{0} \\
\stackrel{0}{0} \\
0\end{array}$ & $\stackrel{+}{\stackrel{*}{S}}$ & $\begin{array}{l}\text { ô } \\
\stackrel{1}{1} \\
\text { în }\end{array}$ & 굼 & $\begin{array}{l}\vec{n} \\
\text { O̊ } \\
0\end{array}$ & 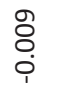 & $\begin{array}{l}\stackrel{0}{7} \\
\stackrel{1}{1}\end{array}$ & ت্ & 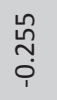 & 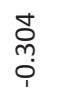 & $\begin{array}{l}\stackrel{\text { ֻ }}{0} \\
\text { ị }\end{array}$ & ָָ & 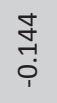 & $\begin{array}{l}\text { ర̊ } \\
\stackrel{0}{0}\end{array}$ & \\
\hline $\begin{array}{l}\frac{00}{0} \\
\frac{0}{\frac{00}{5}} \\
\frac{5}{5}\end{array}$ & 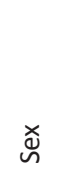 & $\underset{<}{00}$ & $\sum_{\infty}$ & 흠 & 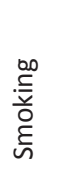 & 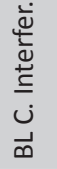 & 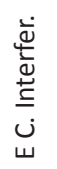 & 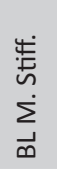 & 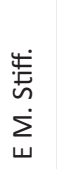 & 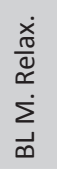 & $\begin{array}{l}\frac{\pi}{\sigma} \\
\Phi \\
\dot{\alpha} \\
\sum \\
\dot{U}\end{array}$ & 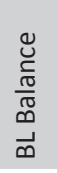 & $\begin{array}{l}\stackrel{\mathscr{U}}{\frac{\pi}{\pi}} \\
\frac{\pi}{\pi}\end{array}$ & 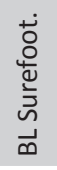 & 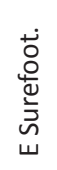 & 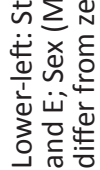 \\
\hline
\end{tabular}


Table 3. Results of t-Tests for each exercising condition

\begin{tabular}{|c|c|c|c|c|c|c|c|c|c|c|}
\hline & \multicolumn{4}{|c|}{ Verum SR-WBV, $6 \mathrm{~Hz}(n=35)$} & \multicolumn{4}{|c|}{ Sham SR-WBV, $2 \mathrm{~Hz}(n=35)$} & \multirow{2}{*}{\multicolumn{2}{|c|}{$\begin{array}{l}\text { Intergroup } \\
\text { Analysis for E }\end{array}$}} \\
\hline & \multirow{2}{*}{$\begin{array}{c}\text { BL } \\
\text { Mean }( \pm S D)\end{array}$} & \multirow{2}{*}{$\begin{array}{c}E \\
\text { Mean }( \pm S D) \\
\end{array}$} & & \multirow[b]{2}{*}{4} & \multirow{2}{*}{$\begin{array}{c}\text { BL } \\
\text { Mean }( \pm S D)\end{array}$} & \multirow{2}{*}{$\begin{array}{c}\mathrm{E} \\
\text { Mean }( \pm \mathrm{SD}) \\
\end{array}$} & \multirow[b]{2}{*}{2} & \multirow[b]{2}{*}{$p$} & & \\
\hline & & & & & & & & & $\mathrm{t}$ & $\mathrm{p}$ \\
\hline $\begin{array}{l}\text { Cognitive } \\
\text { Interference }\end{array}$ & $4.90( \pm 6.19)$ & $1.12( \pm 5.32)$ & 2.49 & $(0.018)$ & $4.39( \pm 9.84)$ & $2.65( \pm 5.22)$ & 1.17 & $(0.252)$ & -1.21 & $(0.229)$ \\
\hline $\begin{array}{l}\text { Muscle } \\
\text { Stiffness }\end{array}$ & $10.54( \pm 8.00)$ & $3.83( \pm 5.39)$ & 5.27 & $(<.000)$ & $13.37( \pm 10.58)$ & $10.11( \pm 10.55)$ & 1.53 & $(0.135)$ & -3.14 & $(0.003)$ \\
\hline $\begin{array}{l}\text { Muscle } \\
\text { Relaxation }\end{array}$ & $75.86( \pm 25.10)$ & $84.51( \pm 20.84)$ & -2.88 & $(0.007)$ & $77.14( \pm 17.51)$ & $82.09( \pm 16.16)$ & -1.65 & $(0.108)$ & 0.55 & $(0.588)$ \\
\hline $\begin{array}{l}\text { Sense of } \\
\text { Balance }\end{array}$ & $47.91( \pm 7.18)$ & $50.94( \pm 9.98)$ & -2.06 & $(0.047)$ & $47.83( \pm 4.43)$ & $47.34( \pm 6.23)$ & 0.35 & $(0.730)$ & 1.81 & $(0.075)$ \\
\hline $\begin{array}{l}\text { Sure- } \\
\text { footedness }\end{array}$ & $48.03( \pm 6.24)$ & $49.29( \pm 9.45)$ & -0.97 & $(0.341)$ & $48.20( \pm 5.62)$ & $46.74( \pm 7.07)$ & 0.85 & $(0.402)$ & 1.28 & $(0.207)$ \\
\hline
\end{tabular}

Left: Verum stochastic resonance whole body vibration $(6 \mathrm{~Hz})$ at Baseline (BL) and exercising condition (E); Middle: Sham stochastic resonance whole body vibration $(2 \mathrm{~Hz})$ at $\mathrm{BL}$ and $\mathrm{E}$; Right: Intergroup Analysis for the exercising condition (verum $\mathrm{E}$ vs. sham E); Interference was calculated as the difference between response-correctness $(100 \%=$ all correct) in congruent trials minus the response-correctness in incongruent trials. Higher cognitive interference stands for lower inhibitory control; Muscle stiffness muscle relaxation was assessed on a 100-point-rating-scale from 0 "not at all comfortable" to 100 "as comfortable as you can imagine"; Sense of Balance and Surefootedness were answered from 0 "a lot worse than usual" to 100 "much better than usual" and with 50 being "same as always"; $p$-values are two-tailed with an a-level set at $5 \%$.

Informed consent statement: All study participants, or their legal guardian, provided informed written consent prior to study enrollment.

CONSORT 2010 statement: The guidelines of the CONSORT 2010 statement had adopted.

was significantly increased after verum $(84.51 \pm 20.84)$, but not after sham SR-WBV $(82.09 \pm 16.16)$. Effect sizes using Cohen's $\mathrm{d}^{33}$ on muscle relaxation in the verum condition was $\mathrm{d}=-0.367$, and in the sham condition $d=-0.293$.

Increase in sense of balance after verum SRWBV (H3)

A significant effect in sense of balance was found after verum $S R-W B V(t=-2.061, P=0.047, n=35)$, but not after sham SR-WBV $(\mathrm{t}=0.347, \mathrm{P}=0.730, \mathrm{n}=35)$. Compared to baseline measurement (verum: 47.91 \pm 7.18 ; sham: $47.83 \pm 4.43$ ) sense of balance increased significantly in verum (50.94 \pm 9.98$)$, but not in sham SR-WBV (47.34 \pm 6.23$)$. Effect size using Cohen's $d^{33}$ on sense of balance in the verum condition was $\mathrm{d}=-0.473$, and in the sham condition $\mathrm{d}=0.139$.

No significant effect was found in surefootedness, whether after verum SR-WBV $(\mathrm{t}=-0.966, \mathrm{P}=0.341, \mathrm{n}$ = 35) nor after sham SR-WBV $(\mathrm{t}=0.849, \mathrm{P}=0.402, \mathrm{n}=$ 35 ). Although not significant, compared to baseline measurement (verum: $48.03 \pm 6.24$; sham: $48.20 \pm 5.62$ ) surefootedness increased in verum (49.29 \pm 9.45$)$ and decreased in sham SR-WBV (46.74 \pm 7.07$)$. Effect size using Cohen's $\mathrm{d}^{33}$ on surefootedness in the verum condition was $\mathrm{d}=-0.149$, and in the sham condition $\mathrm{d}=0.390$.

\section{Discussion}

This study demonstrates that inhibitory control in healthy young adults was improved after one session of SR-WBV.Furthermore, muscle stiffness was reduced and muscle relaxation as well as sense of balance were increased.

These promising effects support earlier findings of sinusoidal WBV on inhibitory control. ${ }^{13-15}$ To our knowledge and database research (pubmed, psycinfo and psyndex on SR-WBV, stochastic resonance, cognition and inhibitory control), no study has been conducted on the topic of SR-WBV on cognitive performance so far.

Surprisingly, correlations in table 2 show that sporty participants in the sham condition had higher cognitive interference at baseline and better balance after the SR-WBV exercise. We could not find this for the verum condition. Although, we would have expected the opposite, a possible explanation could be, that the sporty participants have better coordination skills and are used to training. Trainings are usually not sporadic rather occur coordinated and in rhythm. Therefore, because the body is used to these rhythmic movements from their regular trainings, the verum SR-WBV condition could be experienced as more disturbing than the sham SR-WBV condition because 


\section{Original article}

of the higher frequency of random vibration. Thus, corresponding to the results. If we look at it from the random vibration point of view, the whole pattern gets mixed up and has to find itself again. This needs more time and suggests that a longer training is needed to provoke the effects of the random vibrations.

This seems an interesting topic for further investigation. Additionally, sense of balance and surefootedness showed high correlations at baseline and after exercise in verum and sham condition.

The reduction of muscle stiffness and the increase of muscle relaxation are in line with previous studies of SR-WBV.1-3 Table 2 shows that muscle stiffness and surefootedness were negatively correlated, whereas correlations between muscle relaxation and surefootedness were positive. Although, the increase in sense of balance after SR-WBV is supported by earlier studies of SR-WBV ${ }^{5-7}$ surefootedness was not significantly increased. This could be explained by the relatively young age of the sample. We recommend adding a physical balance test to these highly correlated self-reported measurements in future studies.

Although participants were blind concerning their allocation to the SR-WBV condition, it was not feasible to also blind the examiners. Also, despite the random allocation to the verum or sham SR-WBV group, unfortunately more males were allocated to the verum than to the sham condition. Daniel et al. ${ }^{34}$ did not find any sex differences to the performance in Stroop Test. In this study, sex was also not correlated to interference or to any other study variable.

We performed a randomized controlled trial with a relatively high number of participants $(\mathrm{N}=70)$, which can be seen as a strength of this study. We could show effects on cognitive performance in young and healthy participants, mostly students who are expected to have a high level of attention. As inhibitory control declines with age ${ }^{35}$ we would expect more improvement in older adults. Inhibitory control is also important in gait control, whereas the frequency of falls increases with age. ${ }^{36}$

\section{Falls and inhibitory control}

One out of four accidents in Switzerland happens because of a slip, trip, and fall (STF) incident. ${ }^{37}$ They are even the most frequent accident among office workers. Studies differentiate between single (i.e. accidental falls) and recurrent falls. Accidental falls primarily result from extrinsic causes such as environmental or housing conditions. ${ }^{38}$ Recurrent falls on the other hand usually happen because of intrinsic factors such as advanced age, diseases or gait disorders. ${ }^{38}$ Tromp et al. ${ }^{39}$ could show that especially those suffering from recurrent falls could benefit from preventive and therapeutic exercises, to improve mobility improvement.

$\mathrm{Noll}^{40}$ describes the literature to report relatively few effective treatment options to improve balance and gait in order to prevent falls. Therefore he explains the necessity to explore new intervention approaches. Studies focusing on the relationship of cognition and falls, mostly among older adults, found out that those performing poorly in cognitive performance tests are also more likely to fall. ${ }^{41-43}$

Especially executive functioning, such as inhibitory control seems to be associated with falls. Hausdorff et al. ${ }^{44}$ showed that gait performance in non-demented older adults was associated with executive function, which was measured with the Stroop Test. Anstey et al. $^{41}$ found that a higher risk of recurrent falls was significantly associated with lower executive function of inhibitory control, which showed to be even more important than speed of processing.

As in previous studies of sinusoidal WBV on inhibitory control ${ }^{13-15}$ we implemented a Stroop Test ${ }^{24}$ immediately after the exercise. Future studies may also take long-term effects of SR-WBV on cognition into account.

Further studies on SR-WBV interventions, could test these effects with older adults and focus on gait performance and frequency of falls as it has been shown that gait performance in older adults was associated with Stroop Test results. ${ }^{4}$

Overall, SR-WBV seems an appropriate way to improve not only physiological but newly also psychological measurements. In this first step we could show that SR-WBV exercise reduces interference and increases inhibitory control in a young and healthy sample. Implemented as a worksite intervention, SR-WBV is expected to improve gait and reduce falls, especially in the aging workforce.

\section{Article highlights}

\section{Research background}

SR-WBV has shown to improve musculoskeletal well-being, reduce musculoskeletal pain as well as increase balance and flexibility. Sinusoidal WBV recently showed improvement in cognition, such as inhibitory control. 


\section{Research motivation}

Effects of SR-WBV on cognition have not been tested so far. An increase in inhibitory control could improve gait and reduce risk of falls.

\section{Research objectives}

The objective of this study was to investigate and quantify the acute effects of SR-WBV on inhibitory control, muscle stiffness and muscle relaxation as well as sense of balance and surefootedness.

\section{Research methods}

In this randomized controlled trial participants were randomly allocated to verum $(5 \mathrm{~Hz})$ or sham $(2 \mathrm{~Hz})$ SR-WBV exercising condition. Inhibitory control was assessed with a Stroop Test before and after the exercise. Muscle stiffness, muscle relaxation sense of balance and surefootedness were assessed with questionnaires also before and after the exercise.

\section{Research results}

Paired sample t-test showed a significant increase in inhibitory control for the verum condition $(t=2.949$, $\mathrm{P}=0.018, \mathrm{n}=35)$ but not for the sham condition ( $\mathrm{t}=$ $1.165, \mathrm{P}=0.252, \mathrm{n}=35)$. Muscle stiffness was significantly reduced (verum: $\mathrm{t}=5.273, \mathrm{P}<0.000, \mathrm{n}=35$; sham: $\mathrm{t}$ $=1.533, \mathrm{P}=0.135, \mathrm{n}=35$ ) and muscle relaxation was significantly increased (verum: $\mathrm{t}=-2.879, \mathrm{P}=0.007, \mathrm{n}$ $=35$; sham: $\mathrm{t}=-1.650, \mathrm{P}=0.108, \mathrm{n}=35$ ). Although sense of balance significantly increased (verum: $\mathrm{t}=-2.061, \mathrm{P}$ $=0.047, \mathrm{n}=35$; sham: $\mathrm{t}=0.347, \mathrm{P}=0.730, \mathrm{n}=35$ ), there was no significant change in surefootedness (verum: $\mathrm{t}=$ $-0.966, \mathrm{P}=0.341, \mathrm{n}=35$; sham: $\mathrm{t}=0.849, \mathrm{P}=0.402, \mathrm{n}=35$ ).

\section{Research conclusions}

SR-WBV seems to be an appropriate method to not only improve physiological measurements but newly also cognition, i.e. inhibitory control. In this first step we could show that SR-WBV exercise reduces interference and increases inhibitory control in a young and healthy sample.

\section{Research perspectives}

An association between gait performance in older adults and results in the Stroop Test was found already. Further studies could test the effects of SR-WBV on inhibitory control with older adults and focus on effects on gait performance in order to prevent falls in the aging workforce.

\section{References}

1. Burger C, Schade V, Lindner C, et al. Stochastic resonance training reduces musculoskeletal symptoms in metal manufacturing workers: A controlled preventive intervention study. Work. 2012;42(2):269-78.

2. Elfering A, Arnold S, Schade V, et al. Stochastic resonance whole-body vibration, musculoskeletal symptoms, and body balance: a worksite training study. Saf Health Work. 2013;4(3):149-55.

3. Pang MY. Whole body vibration therapy in fracture prevention among adults with chronic disease. World J Orthop. 2010;1(1):20.

4. Elfering A, Zahno J, Taeymans J, et al. Acute effects of stochastic resonance whole body vibration. World J Orthop. 2013;4(4):291.

5. Faes Y, Maguire C, Notari M, et al. Stochastic Resonance Training Improves Balance and Musculoskeletal Well-Being in Office Workers: A Controlled Preventive Intervention Study. Rehabil Res Pract. 2018;2018.

6. Elfering A, Schade V, Burger C, et al. Stochastic resonance training at work reduces musculoskeletal pain in nurses. Duffy $\mathrm{V}$, Lightner N Advances in Human Aspects of Healthcare USA: AHFE Conference; 2014.

7. Elfering A, Schade V, Stoecklin L, et al. Stochastic resonance whole-body vibration improves postural control in health care professionals: a worksite randomized controlled trial. Workplace Health Saf. 2014;62(5):187-96.

8. 8. Awan, R. I., Khan, N., \& Perveen, S. (2017). The Effect of WBV on Balance, Mobility and Strength in Aging Adults: A Systematic Review. Biological Systems: Open Access, 6(1), 179-185. doi: 10.4172/2329-6577.1000179

9. Rogan S, Hilfiker R, Schenk A, et al. Effects of whole-body vibration with stochastic resonance on balance in persons with balance disability and falls history-a systematic review. Res Sports Med. 2014;22(3):294-313.

10. Rogan S, de Bruin ED, Radlinger L, et al. Effects of whole-body vibration on proxies of muscle strength in old adults: a systematic review and meta-analysis on the role of physical capacity level. Eur Rev Aging Phys A. 2015;12(1):12.

11. Kessler J, Radlinger L, Baur H, et al. Effect of stochastic resonance whole body vibration on functional performance in the frail elderly: A pilot study. Arch Gerontol Geriat. 2014;59(2):305-11.

12. Rogan S, Hilfiker R, Schmid S, et al. Stochastic resonance whole-body vibration training for chair rising performance on untrained elderly: A pilot study. Arch Gerontol Geriat. 2012;55(2):468-73.

13. Fuermaier AB, Tucha L, Koerts J, et al. Good vibrations-effects of whole body vibration on attention in healthy individuals and individuals with ADHD. PloS One. 2014;9(2):e90747.

14. Regterschot GRH, Van Heuvelen MJ, Zeinstra EB, et al. Whole body vibration improves cognition in healthy young adults. PloS One. 2014;9(6):e100506.

15. den Heijer AE, Groen Y, Fuermaier AB, et al. Acute effects of Whole Body Vibration on inhibition in healthy children. PloS One. 2015;10(11):e0140665.

16. Martin J. Neuroanatomy: text and atlas Mcgraw-Hill. New York. 2003.

17. Braak H, Braak E, Yilmazer D, et al. Topical review: functional anatomy of human hippocampal formation and related structures. J Child Neurol. 1996;11(4):265-75.

18. Van der Zee E, Riedel G, Rutgers E, et al. Enhanced neuronal activity in selective brain regions of mice induced by 


\section{Original article}

whole body stimulation. Federat Europ Neurosci Soc Abs. 2010;5(024.49):R2.

19. Boerema AS, Heesterbeek M, Boersma SA, et al. Beneficial effects of whole body vibration on brain functions in mice and humans. Dose-Response. 2018;16(4):1-10.

20. Robbins TW. Dissociating executive functions of the prefrontal cortex. Philos Trans R Soc Lond B Biol Sci. 1996;351(1346):1463-71.

21. Baddeley AD, Della Sala S. Working memory and executive control. Philos Trans R Soc Lond B Biol Sci. 1996;351(1346):1397-404.

22. Miyake A, Friedman NP, Emerson MJ, et al. The unity and diversity of executive functions and their contributions to complex "frontal lobe" tasks: A latent variable analysis. Cogn Psychol. 2000;41(1):49-100.

23. Cummings JL. Clinical neuropsychiatry: Grune \& Stratton; 1985.

24. Stroop JR. Studies of interference in serial verbal reactions. J. Exp. Psychol. 1935;18(6):643.

25. Fischer M, Vialleron T, Laffaye G, et al. Long-term effects of whole-body vibration on human gait: A systematic review and meta-analysis. Front Neurol. 2019;10.

26. Morel DS, da Fontoura Dionello C, Moreira-Marconi E, et al. Relevance of whole body vibration exercise in sport: a short review with soccer, diver and combat sport. Afr J Tradit Complem. 2017;14(4S):19-27.

27. Faes Y, Banz N, Buscher N, et al. Acute effects of partial-body vibration in sitting position. World J Orthop. 2018;9(9):156-64.

28. Boonstra AM, Oosterlaan J, Sergeant JA, et al. Executive functioning in adult ADHD: a meta-analytic review. Psychol Med. 2005;35(8):1097-108.

29. Laird AR, McMillan KM, Lancaster JL, et al. A comparison of label-based review and ALE meta-analysis in the Stroop task. Hum Brain Mapp. 2005;25(1):6-21.

30. Mathias JL, Wheaton P. Changes in attention and information-processing speed following severe traumatic brain injury: a meta-analytic review. Neuropsychology. 2007;21(2):212.

31. 31. Luu, D., Aptekar-Cassels, W., Hanson, L., \& Murphy, K.
(2017). Keyboard latency. Available from: https://danluu.com/ keyboard-latency/ . Retrieved June 25, 2020.

32. Field A. Discovering statistics using SPSS. London: Sage publications; 2009.

33. Cohen J. A power primer. Psychol Bull. 1992;112(1):155.

34. Daniel DB, Pelotte M, Lewis J. Lack of sex differences on the Stroop Color-Word Test across three age groups. Percept Mot Skills. 2000;90(2):483-4.

35. Hasher L, Stoltzfus ER, Zacks RT, et al. Age and inhibition. J Exp Psychol Learn. 1991;17(1):163.

36. Organization WH. WHO global report on falls prevention in older age: World Health Organization; 2008.

37. 37. SUVA. Unfallstatistik UVG 2017, Koordinationsgruppe für die Statistik der Unfallversicherung, K.f.d.S.d. Unfallversicherung, Editor. 2017. Available from: https://www.unfallstatistik. ch/d/publik/unfstat/pdf/Ts17.pdf . Retrieved June 25, 2020.

38. Dunn JE, Rudberg MA, Furner SE, et al. Mortality, disability, and falls in older persons: the role of underlying disease and disability. Am J Public Health. 1992;82(3):395-400.

39. Tromp A, Smit J, Deeg D, et al. Predictors for falls and fractures in the Longitudinal Aging Study Amsterdam. J Bone Miner Res. 1998;13(12):1932-9.

40. Noll DR. Management of falls and balance disorders in the elderly. J Am Osteopath Assoc. 2013;113(1):17-22.

41. Anstey KJ, Wood J, Kerr G, et al. Different cognitive profiles for single compared with recurrent fallers without dementia. Neuropsychology. 2009;23(4):500.

42. Buracchio TJ, Mattek NC, Dodge HH, et al. Executive function predicts risk of falls in older adults without balance impairment. BMC Geriatrics. 2011;11(1):74.

43. Herman T, Mirelman A, Giladi N, et al. Executive control deficits as a prodrome to falls in healthy older adults: a prospective study linking thinking, walking, and falling. J Gerontol A-Biol. 2010;65(10):1086-92.

44. Hausdorff JM, Yogev G, Springer S, et al. Walking is more like catching than tapping: gait in the elderly as a complex cognitive task. Exp Brain Res. 2005;164(4):541-8. 